DOI 10.4467/25439561KSR.21.010.14421

\author{
LECH MiODYŃSKI (D) https://orcid.org/0000-0003-2053-2277 \\ Uniwersytet Śląski \\ w Katowicach
}

\title{
SPOŁECZNO-KULTUROWE ZAPLECZE IDEOLOGII SOCJALIZMU W CZARNOGÓRZE
}

\author{
SOCIO-CULTURAL BASIS OF THE IDEOLOGY OF SOCIALISM \\ IN MONTENEGRO
}

\section{Streszczenie}

$\mathrm{W}$ artykule omawia się w perspektywie chronologicznej i problemowej podstawowe przyczyny skutecznej adaptacji idei socjalistycznych w Czarnogórze w XX wieku. Obok źródeł myśli serbskiej, rosyjskiej i niemieckiej ważną rolę odegrał tu miejscowy paradygmat etyki heroicznej, kolektywizmu i egalitaryzmu, a także warunki ekonomiczne, związki polityczne z Rosją oraz słabość tradycji feudalnej i mieszczańskiej. Przedstawione przykłady ilustrują różne warianty rozumienia socjalizmu: jako postpatriarchalnego solidaryzmu, rewolucjonizmu etycznego, komunizmu utopijnego i antybiurokratyzmu. Elementy tych koncepcji dostrzegalne są zarówno w ich pierwszych czarnogórskich manifestacjach z lat 1905-1920, działalności międzywojennej KPJ, jak i w rewolucyjnym dyskursie antyfaszystowskiego ruchu partyzanckiego. Podobnie oryginalna geneza społeczno-kulturowa cechuje dokumentację zjawiska z okresów sporu z Międzynarodówką Komunistyczną (od 1948, w tym wypowiedzi Milovana Đilasa), budowy ustroju socjalizmu samorządowego i wydarzeń z lat 1987-1989.

\section{Abstract}

The paper discusses, in the chronological and problematic perspective, the essential reasons for the effective adaptation of socialist ideas in Montenegro in 20th century. Apart from sources of Serbian, Russian and German thought, it was local heroic ethics, collectivism and egalitarianism paradigm, economic conditions, political relations with Russia, and also 
instability of feudal and bourgeois tradition that were crucial to this reception. The examples presented here illustrate various variants of the understanding of socialism: as post-patriarchal solidarism, ethical revolutionarism, utopian communism and anti-bureaucraticism. The elements of these conceptions can be noticed in their first Montenegrin manifestations of 1905-1920, the activity of the interwar YCP as well as in the revolutionary discourse of the antifascist guerrilla movement. Similarly original socio-cultural origin characterises the documentation of the depicted phenomenon in the periods of dispute with Communist International (from 1948, including Milovan Djilas statements), construction of the self-government socialism system and events of 1987-1989.

Słowa kluczowe: Czarnogóra, socjalizm, marksizm, rewolucja proletariacka, etyka heroiczna

Keyw ords: Montenegro, socialism, Marxism, proletarian revolution, heroic ethics

Zanim trudne dzieło zrównoważenia wielu interesów narodowych, zgrania aspiracji nierównomiernie rozwiniętych regionów i zamrożenia antagonizmów religijnych doczekało się częściowej i przejściowej - do 1991 roku - realizacji w socjalistycznym państwie jugosłowiańskim, jego ideowy fundament musiał zostać scalony w uniwersalnym wzorcu postępu, wyzwolenia ekonomicznego i redystrybucji własności. W monarchii przedwojennej przed zjednoczeniem w 1920 roku radykalnych ruchów lewicowych każda ich narodowa tradycja wyrastała z odrębnych korzeni, choć łączyły je często wspólne fascynacje teoretyczne, lektury i kontakty. Dla Serbów najważniejsza była myśl Svetozara Markovicia z jego inspiracjami wizją Nikołaja Czernyszewskiego i diagnozami Pierre'a Proudhona oraz rozwinięciem utopii agrarystycznej i antymonetarystycznej; po nim radykałowie (jak Adam Bogosavljević) próbowali nadać ramy organizacyjne chłopskiej rewolucji, a następnie Dimitrije Tucović na początku XX wieku poszedł śladami socjaldemokratów berlińskich, licząc na efektywną presję ruchu związkowego i z czasem zbliżając się do pozycji leninowskich. Na ziemiach chorwackich pierwsi socjaliści - z dominacją reformistów - terminowali u robotniczych aktywistów i teoretyków z Grazu, Wiednia czy Budapesztu; współpraca z Węgrami sięgała jeszcze czasów Komuny Paryskiej (wpływu poglądów Ferdinanda Lassalle’a). Także i tu w okresie kryzysu w monarchii austro-węgierskiej (od 1904 roku) do głosu dojdą interesy chłopskie (zwłaszcza w Dalmacji), a dużym poparciem cieszyć się będą chrześcijańscy socjaliści. Podobnie było w Słowenii, pozostającej w orbicie idei austromarksizmu, a ostatecznie rozdartej między mało skuteczną orientacją antyklerykalno-laicką a opcją chrześcijańsko-społeczną (Janez Krek, Aleš Ušeničnik); pewien rezonans wywołały też poglądy socjaldemokratów włoskich i czeskich. W środowisku bośniackich muzułmanów 
dopiero w pierwszej dekadzie XX wieku powstały nieliczne organizacje o antyfeudalnym jeszcze nastawieniu (jak antyaustriacka Muslimanska narodna organizacija), a równolegle szukano przydatnych rozwiązań teoretycznych u austriackich i szwajcarskich socjaldemokratów, poza tym także w Turcji. Dla Macedończyków natomiast przed 1912 rokiem centra ideowego oddziaływania mieściły się zarówno w Salonikach i Sofii, jak i w Rosji, przy czym w dużej mierze hasła społeczne zespoliły się tu z narodowo-terytorialnymi ${ }^{1}$.

$\mathrm{Na}$ tym tle rozpowszechnienie oraz nieprzeciętna żywotność socjalistycznego paradygmatu $\mathrm{w}$ izolowanej wcześniej przez wiele stuleci w plemienno-militarnym ustroju Czarnogórze, której egalitarne prawo zwyczajowe i tradycja kultu zbiorowej wolności wyróżniały ją z południowosłowiańskiego otoczenia, stanowi zjawisko zarazem historyczno-polityczne i psychospołeczne. Wśród jego genetycznych źródeł zwykle wymienia się głęboki materialny niedostatek panujący w jałowym górskim środowisku, naturalne skłonności kolektywistyczne i aksjologię równości - wynikające z zasad permanentnej walki przeciwko osmańskim najeźdźcom od XVI wieku, brak w przeszłości istotnego doświadczenia feudalizmu (co kształtowało honorowe egzekwowanie bez oporów elementarnej sprawiedliwości w stosunku do każdej postaci zależności człowieka) i wreszcie bezkonfliktowe po II wojnie światowej wywyższenie chłopskiego - lecz jednak nie typowo rolniczego - społeczeństwa do statusu współwłaściciela środków produkcji de facto z pominięciem fazy jego adaptacji do mieszczańsko-kapitalistycznych kategorii ekonomicznych czy świadomościowych. Dla fundamentalnej we wszystkich socjalistycznych koncepcjach kwestii własności miało to znaczenie podstawowe.

Nadmiernej kumulacji dóbr materialnych przez jednostki przeciwdziałały tu od dawna regulacje wprowadzane przez zbory - ponadplemienne reprezentacje poszczególnych „wspólnot wojennych”, a skodyfikowany w obyczaju i normach zachowania etos heroiczny dodatkowo przyczyniał się do dyskredytacji wszelkich nierówności majątkowych i zbytku. Jednocześnie utrzymywała się długo charakterystyczna dla form anarchii plemiennej tzw. junačka sloboda - prawo do niezgody, także zbrojnej, na jakikolwiek przepis prawny uznawany za zamach na osobistą wolność jednostki. Z tym zwyczajem próbował uporać się władyka Petar II Petrović Njegoš w połowie XIX wieku, a ustawodawstwo jego świeckiego następcy Danila I zmierzało do ogra-

${ }^{1}$ Zob. Povijest Saveza komunista Jugoslavije, red. S. Stojanović et al., Beograd, Komunist, 1985, ss. 5-51. Szczególnego zaakcentowania wymaga oddziaływanie poglądów Svetozara Markovicia - wielostronnie już przeanalizowanych w ogromnej liczbie publikacji (także w formie monografii polskojęzycznych - zob. na przykład H. Pisarek, Filozofia Svetozara Markovicia (1846-1875): z historii marksizmu w Serbii, Wrocław, Wydawnictwo Uniwersytetu Wrocławskiego, 1981; E. Bujwid-Kurek, Myśl polityczna i państwowo-ustrojowa Svetozara Markovicia (1846-1875), Księgarnia Akademicka, Kraków 2000). 
niczenia negatywnych skutków podobnych do zawartych w albańskim kanunie Leki Dukagjiniego zasad krwawej zemsty, w ramach której często niszczono też zasiewy i zapasy żywności skonfliktowanej strony, zmuszając ją do przeżycia za cenę upokarzającej wymiany broni na zboże. Tradycyjnym zajęciem wielu klanów jeszcze w XVIII stuleciu był rozbój dokonywany na kupieckich karawanach przemieszczających się z Dubrownika do Sandžaku (oczywiście także na Turkach, ale też majątkach cerkiewnych), zaś poczucie materialnej sprawiedliwości w stosunku do dóbr innych niż zdobyczne odnosiło się co najwyżej do skromnych zasobów prymitywnej hodowli i uzbrojenia - przy niemal całkowitym braku rzemiosła, jakiegokolwiek systemu monetarnego aż do połowy wieku XIX (a do 1906 roku użyciu wyłącznie waluty austriackiej) i jeszcze dłuższej nieobecności opieki zdrowotnej oraz bilansu handlowego powstającej wówczas struktury państwowej zależnym głównie od koniunktury na bazarach w przygranicznych miasteczkach Turcji ${ }^{2}$. W takich wyjściowych warunkach, pogłębionych do czasu większej emigracji zarobkowej do Serbii całkowita nieobecnością u Czarnogórców perspektywy porównawczej standardów życia w różnych krajach, rozpoczęła się po Kongresie Berlińskim za panowania księcia Nikoli I preindustrialna i wczesnourbanizacyjna faza rozwoju społeczno-gospodarczego. Jej kierunek wyznaczały nawracające zagrożenia klęską głodu (którym władca próbował przeciwdziałać, snując między innymi plany powiększającego rolny areał osuszenia całego Jeziora Szkoderskiego), czemu towarzyszyło przenikanie do kruchego państewka kapitału handlowego oraz bankowego z Austrii i związanego z nią Triestu, podobnego pochodzenia rozwój niewielkich inwestycji przemysłowych w leśnictwie i branży spożywczej, uzależnienie od kompanii weneckich w przetwórstwie tytoniu, a na wiejskiej prowincji gwałtowny i niszczycielski rozwój lichwy. Cienie typowo spekulacyjnej, generującej zadłużenie gospodarki nałożą się na przełomie XIX i XX wieków na zmierzch złączonej z etosem zmilitaryzowanej społeczności wizji heroicznego panmoralizmu jednostki i kolektywu (formuła čojstvo i junaštvo), gdy dworskie intrygi, rywalizacja o nadania ziemskie i napływ zagranicznych towarów spowodują rozprzężenie w szeregach nieco wzbogaconych na dowódczych stanowiskach dawnych „szlachetnych biedaków” - jak wojowniczych obrońców „słowiańskiej Sparty" przed Osmanami nazywali niektórzy egzaltowani zachodni publicyści. Realia takie legły u podstaw opinii, iż jedynym liczącym się kapitalistą było tu państwo, pozbawione wszak czynnego kapitału.

Nie bez znaczenia dla historycznego i kulturowego kontekstu myślenia ówczesnych Czarnogórców o sensie ich ziemskiego losu była również symbiotyczna więź z carską Rosja, której kreatorzy planów polityczno-militarnych na Bałkanach po-

\footnotetext{
${ }^{2}$ Szerzej o ówczesnych uwarunkowaniach socjoekonomicznych: R. Radonjić, Socijalizam u Crnoj Gori, Podgorica, Matica crnogorska, 2013, ss. 32-51; B. Marović, Ekonomska istorija Crne Gore, Podgorica, CID, 2006 (t. I); Pobjeda, 2008 (t. II).
} 
czątkowo upatrywali w miejscowym związku prawosławnych plemion dźwignię rewolty antytureckiej - od entuzjastycznej odpowiedzi na wezwanie do walki przez Piotra Wielkiego (1711), gwarancji opieki ze strony Katarzyny II w zamian za służbę cesarstwu (1766), przez alternatywę przesiedlenia całego narodu na rosyjski Kaukaz za panowania Petara I Petrovicia Njegoša, chirotonię władyki Petara II w Petersburgu (1833) i wpływ dyplomacji carskiej na politykę księcia Nikoli, aż do trwającego dziesięciolecia dofinansowania całej miejscowej organizacji wojska ${ }^{3}$. Nic zatem dziwnego, że w tak ukształtowanym społeczeństwie - podobnie jak w wielu innych krajach słowiańskich o chłopskiej dominancie - najlepiej w drugiej połowie XIX wieku przyjmowała się tu, zresztą bez głębszej refleksji, rosyjska myśl demokratyczno-rewolucyjna spod znaku Aleksandra Hercena i Czernyszewskiego (pośrednikami w jej popularyzacji byli Serbowie), rusofilstwo tradycyjnie miało charakter bezwarunkowy i utopijny, stalinowski dogmatyzm święcił w latach 1944-1948 triumfy jak nigdzie indziej w Jugosławii, a kariery bezkompromisowych czarnogórskich oficerów w titowskiej armii zapewniły im opinię najbardziej oddanych komunistów w mundurach spośród wszystkich narodowości federacji.

Istniała wszak głęboka sprzeczność pomiędzy rzeczywistością najbardziej w regionie upośledzonych ekonomicznie ziem czarnogórskich (gdzie nawet rolnictwo z powodu warunków naturalnych było kompletnie nieopłacalne) a upowszechnianymi w Serbii przez Svetozara Markovicia w latach siedemdziesiątych agrarystycznymi postulatami narodników odnoszących się do idei samowystarczalnych wspólnot rolnych i analogicznie nie mogły tu też mieć zastosowania zorientowane na zachodni system wytwórczy elementy ekonomii politycznej Karola Marksa. Powstała w Czarnogórze ze znacznym opóźnieniem mieszanka ideowa lewicowych recept społeczno-politycznych okaże się więc niespójną kontaminacją ,etycznego rewolucjonizmu” i antybiurokratyzmu z pierwiastkami postpatriarchalnego solidaryzmu i utopijnego komunizmu4. W Serbii tymczasem wyzwolone od 1833 roku chłopstwo zasiedlało miasta i próbowało przez aktywność parlamentarną wpływać na kształt dynastycznego państwa (jak z końcem wieku rzecznik tej warstwy społecznej, republikanin Dragiša Stanojević), a młoda inteligencja (Ujedinjena omladina srpska) wiedzę o ideach socjalistycznych czerpała obficie z Rosji, Niemiec i Francji. Dyskusję o skali równości i granicach wolności toczoną w tym środowisku głównie $\mathrm{z}$ inspiracji pism samego Markovicia (znającego dobrze specyfikę Czarnogóry) cechował już na wstępie wysoki poziom utopizmu, przy czym na czoło poglądów zwanych zbiorczo myśla krytycznq wysuwały się idee Nikołaja Czernyszewskiego, wspierane lekturą tekstów

${ }^{3}$ Zob. R. Raspopović, Crna Gora i Rusija: ogledi i eseji, Podgorica, Istorijski institut Crne Gore, 2005; M. Kusovac, Odnos Crne Gore i Rusije, „Matica” 2013/2014, nr 56-57, ss. 53-72 i inne opracowania.

${ }^{4}$ Zob. R. Radonjić, Socijalizam..., op.cit., ss. 15-16, 67-68, 106, 112. 
Dmitrija Pisariewa, Piotra Ławrowa i emigracji w Szwajcarii, Ferdinanda Lassalle’a, Louisa Blanca, a dopiero w późnej fazie - i z początkowymi zastrzeżeniami-Marksa. Zarówno w Serbii, jak i w Czarnogórze dojrzewa wówczas przekonanie, iż ostatecznemu wyparciu Turków z południowosłowiańskich terytoriów towarzyszyć powinno rozmaicie pojmowane wyzwolenie ekonomiczne, za ugrupowaniami socjaldemokratycznymi coraz częściej rozumiane w wymiarze niemieckiej koncepcji internacjonalistycznej, a w końcu monoetniczne narodnictwo zostanie zarzucone po roku 1899 - czyli na etapie istnienia II Międzynarodówki. Dodatkowo u Czarnogórców pojawia się po raz pierwszy w tym ideowym kontekście sprawa emancypacji klasowej połączonej z narodową, choć pozostanie ona jeszcze na długo niedopowiedziana. Jej ważność jako coraz istotniejszej kwestii tożsamościowej przeczuwał za to po przeciwnej stronie ideowej barykady książę Nikola I, ogłaszając w 1905 roku w Cetinju konstytucję, a w 1910 proklamując królestwo - co z jednej strony w obawie przed reperkusjami pierwszej rewolucji rosyjskiej ściaggało z niego odium ostatniego absolutnego władcy Europy, a z drugiej czyniło symboliczne aluzje do prawomocności państwa niezależnego od Serbów narodu.

Gotowe - choć niemal o pół wieku później odtworzone - serbskie wzorce w postaci koncepcji chłopskiego państwa z jego masową partią ludową i wiejskiej samorządności zinstrumentalizowały z początkiem nowego stulecia w tej części Półwyspu Bałkańskiego nigdy tu nie zrealizowane ideały rewolucji francuskiej i jednocześnie użytkowo wyzyskały pewne wartości oświeceniowe na czele z demokratyzacją prawa i nobilitacją zasady rozumnego postępu. Niezależnie od tego zabrzmiał odległy echem w całym serbskojęzycznym świecie Marksowski postulat od-przedmiotowienia pracy (zniesienia jej alienacji), któremu nadawano rozmaite znaczenia w zależności od regionalnej specyfiki gospodarczej. Manifest komunistyczny obecny był w ofercie księgarskiej w Cetinju w latach siedemdziesiątych XIX wieku, jednak nie odnotowano żadnej recepcji tego faktus. Prócz tego Niemcy, Rosję, Serbię i Czarnogórę różniły od lat osiemdziesiątych proporcje między socjaldemokratycznymi i kadrowo-rewolucyjnymi frakcjami lewicy. Podobnie sprawa wyglądała z wyborem priorytetów: honorowej wolności bez jakichkolwiek związków z państwem bądź materialnego dobrobytu. Skupieni na radykalnej działalności spiskowej Czarnogórcy uciekali od wpływów konserwatywnej Austrii bezpośrednio w stronę rosyjskiej myśli rewolucyjnej, nie skrępowani tak jak Serbowie teoriami francusko-niemieckimi i rodzimymi koncepcjami organicystycznego nacjonalizmu, których sami nie zdążyli wypracować. Owa jaskrawo proletariacka postawa będzie znakiem rozpoznawczym pierwszych orędowników idei socjalistycznej także dlatego, że nie akceptowała

${ }^{5}$ Zob. Đ. Pejović, Društveno-filozofski pogledi u Crnoj Gori od početka XIX do sredine XX vijeka, Titograd, CANU, 1980, s. 186. 
monarchistycznej polityki belgradzkiej dążącej do restytucji terytorialnej średniowiecznego „carstwa Dušana” (mającego też objąć niezależną nadal Czarnogórę), i stąd pragmatycznie sprzyjała działalności takich Serbów jak Dimitrije Tucović głoszących postulat przyszłej równoprawnej federacji dwóch bliskich sobie państw. Aktywny w różnych prowincjach serbskich Vasa Pelagić publikował w periodyku „Crnogorac” artykuły o Komunie Paryskiej, a wtórował mu wczesny socjalista Dušan Brkanović, lecz były to raczej przed 1905 rokiem głosy ledwie słyszalne ${ }^{6}$.

Ta przełomowa data zapoczątkowała rosnący opór demokratycznie nastawionej młodzieży studenckiej przebywającej w Belgradzie przeciw despotyzmowi władzy książęcej, czego konsekwencjami były tzw. bombaška afera (1907, pierwsza nieudana akcja zbrojna - identyfikująca odtąd radykalne środowiska z emisariuszami z Serbii), następnie spisek antymonarchistyczny majora Nikoli Mitrovicia stłumiony w 1909 roku oraz początki działalności czasopiśmienniczej („Naprijed” [1911] z redakcją w Belgradzie - poza zasieggiem władzy Nikoli I). Charakterystyczny przedstawiciel ówczesnego ruchu socjalistycznego to kelner-poliglota z Kotoru, Adolf Muk, który po ukończeniu technikum w Wenecji rozwinął szeroką działalność publicystyczną, obejmującą krótkotrwale ukazujące się periodyki w Sarajewie, Belgradzie, Splicie, Wiedniu czy Podgoricy. Specyfika jego profesji nie była bez znaczenia w perspektywie słabej industrializacji wielu regionów południowej Słowiańszczyzny - na przykład właśnie strajki kelnerów stanowiły charakterystyczny rys rozwoju aktywności lewicowej w międzywojennym Skopje. Natomiast Boka Kotorska jako jedyna w Czarnogórze posiadała tradycje samoorganizacji związkowej, i to tam właśnie miał miejsce dwudniowy, zakończony aresztowaniami antywojenny bunt marynarzy (1918), którym na 40 austriackich okrętów dostarczano socjalistyczną prasę o różnych orientacjach. Gdy jednak po rewolucji październikowej nadzór nad światowym ruchem robotniczym przeszedł w ręce leninowskiej II Międzynarodówki (1919), ideały i interesy nielicznych czarnogórskich socjalistów stłumiono $\mathrm{w}$ doktrynie internacjonalistycznej, wyrażonej jasno w dokumentach zjednoczeniowych Komunistycznej Partii Jugosławii (1920, wraz z organizacją młodzieżową SKOJ) operujących terminologią „klasowej jedności trzech plemion w jednej nacji”’ W tymże roku upadła trwająca 403 dni pierwsza czerwona komuna w nadmorskim Petrovcu, oddolnie dokonawszy radykalnej reformy rolnej i finansowej. Nim w 1921 roku ogłoszono centralnie delegalizację komunistycznej partii, w Czarnogórze zdołano przeprowadzić strajki w obuwnictwie i demonstracje przeciw drożyźnie oraz rozpropagować zdobycze Rosji radzieckiej. Jakkolwiek utopijna wizja bezklasowej republiki rad nad południowym

${ }^{6} \mathrm{O}$ pionierach ruchów lewicowych zob. m.in. Č. Pejović, Komunistička partija Jugoslavije u Crnoj Gori 1919-1941, Podgorica, CID, 1999.

${ }^{7}$ Zob. Povijest Saveza..., op.cit., s. 63. 
Adriatykiem nie opuszczała umysłów wielu młodych działaczy, to jednak skazani oni byli tylko na działalność samopomocową w patriarchalnym środowisku zadłużonych chłopów i niepiśmiennych chłopek, niezdolnych samodzielnie do wprowadzenia dyktatury proletariatu przemysłowego i wywłaszczeń - w kraju gdzie do końca lat trzydziestych w 24 zakładach zatrudniano zaledwie 1400 robotników, miejsc pracy było proporcjonalnie kilkunastokrotnie mniej niż w Serbii ${ }^{8}$, a niedokapitalizowane banki musiały w dużej mierze finansować wysokie koszty transportu towarów przez niedostępne pasma górskie. Trudno tu zatem było mieć wyobrażenie o imperialistycznej fazie rozwoju kapitalizmu, znanej Czarnogórcom ze słyszenia głównie $\mathrm{z}$ doniesień Vukašina Markovicia - byłego słuchacza seminarium duchownego w Charkowie, lekarza i publicysty, który jako „zawodowy rewolucjonista” i mąż rewolucjonistki francuskiej Jeanne Labourbe powraca w 1921 roku z Rosji, gdzie należał do bliskich współpracowników Włodzimierza Lenina (zachowała się ich wspólna fotografia na Placu Czerwonym), jednak skompromitowany ,awanturnictwem” zostaje odsunięty od ścisłego kierownictwa bolszewickiego i po nieudanej trzyletniej próbie wywołania proletariackiej rewolty w swej ojczyźnie wspiera w 1926 roku ludową rewolucję w Chinach - prawdopodobnie jako jedyny południowy Słowianin. Szkoli następnie sowietofilów walczących później w międzynarodowych brygadach w Hiszpanii (Czarnogórców - doskonałych dywersantów częściowo przybyłych z ZSRR - było tam wielu) oraz Albanii i kończy jako ofiara stalinowskiego procesu. W zachowanej autobiografii (wcześniejszej odpowiedzi na ankietę) z 1928 roku Marković wyznaje: „У меня нет ни ложки, ни кошки. Моя семья - пролетариат всего мира. Моя национальность - человечество", а znający go świadkowie potwierdzają, że jako jeden z pierwszych rozwinął kult Lenina, będącego dla niego jednocześnie „Spartakusem, Campanellą, Stieńką Razinem i Tomaszem Morusem”. Jego ideowe dojrzewanie przebiega równolegle do ewolucji tzw. postępowych poglądów w całej wschodniej Europie, gdzie tendencje socjaldemokratyczne ostatecznie zanikały, ustępując miejsca wyłącznie zbrojnym receptom na usunięcie klasowych sprzeczności.

W Czarnogórze komuniści przeorganizowani po wcieleniu kraju do serbskiego terytorium Jugosławii w 1918 roku gromadzili się od 1924 nad grobem tutejszego prekursora ruchu rewolucyjnego, prawnika i publicysty Jovana Tomaševicia, zyskującego z czasem w półlegalnej periodyce („Radni narod” - 1927-1928) miano inkarnacji ideologii proletariackiej. Propagowały ją (zwłaszcza w Nikšiciu) formalnie

${ }^{8}$ Zob. Crna Gora, red. M. Maletić, Beograd, Književne novine - Stručna knjiga, 1976, s. 298.

${ }^{9}$ Жанна Лябурб - француженка в Одессе, [w:] https://agesmystery.ru/rubriki/zagovory-i-afery/zhanna-lyaburb-francuzhenka-v-odesse/ [dostęp: 20.03.2020]; P. Požar, Jugosloveni žrtve staljinskih čistki, Beograd, Nova knjiga, 1989, s. 54. Zob. także: D. Vujović, Učešće Vukašina Markovića u oktobarskoj revoluciji i njeni odjeci u Crnoj Gori, [w:] Prilozi za istoriju socijalizma, t. 5, red. P. Damjanović et al., Beograd, Institut za izučavanje radničkog pokreta, 1968, ss. 501-508. 
uznawane przez władze młodzieżowe związki sportowe, upowszechniające antypaństwowe „treści rewolucyjne” podczas nielegalnych wypraw górskich. W czarnogórskiej - zdecydowanie pryncypialnej - części KPJ nie było wówczas frakcyjnych walk, za to istniały specyficzne rysy języka ideowego: zamiast marksistowskiego symbolu „wspólnej ojczyzny robotników” pojawiała się raczej etyczno-heroiczna frazeologia ,powszechnej sprawiedliwości moralnej”, uzupełniana płomiennym rusofilstwem, któremu towarzyszyła niezwykle powierzchowna wiedza o samej Rosji - i postawa taka nie różniła się wiele od dawnego, nieco naiwnego kultu potęgi carskiego imperium. Na łamach rozkwitających w pierwszej połowie lat trzydziestych czasopism „Granit”, „Valjci” i „Razvršje” oraz w licznych odezwach występowano więc w obronie Kraju Rad przed zewnętrzną interwencją, przeciwko krzywdzącemu podziałowi administracyjnemu kraju na wyznaczane w poprzek podziałów etnicznych banowiny, czy wręcz apelowano o niezwracanie pożyczek bankom i lichwiarzom ${ }^{10}$. Lewicowi publicyści z tego kręu, Stojan Cerović czy Đorđe Lopičić, wykazywali się wielką żarliwością w służbie egalitarnej idei, choć na przykład pierwszy z nich - frankofil po studiach na Sorbonie - był erudycyjnym literaturoznawcą i wszechstronnym działaczem kulturalnym o dużej wrażliwości estetycznej. Stanowił on wszak raczej wyjątek, bowiem w gronie przyszłych budowniczych socjalistycznej republiki w SFRJ znaleźli się w większości raczej ludzie tacy jak jej premier Blažo Jovanović - zmarły w 1976 roku pragmatyczny aktywista partyjny i powierzchowny ideolog. W drugiej połowie lat trzydziestych zorientowano się poza tym, jak wysoka może być cena konfrontacji z aparatem państwowej przemocy i zwrócono się taktycznie w stronę budowania społecznej świadomości nie poprzez organizację krwawych buntów, lecz zakładanie kół samokształceniowych i bibliotek. W Uniwersytecie Belgradzkim studentom czarnogórskim przewodził Vojin Niklić, sam określający się mianem rewolucjonisty totalnego. W tym okresie wyraziste zjawisko literackie, jakim była w całej międzywojennej Jugosławii tzw. literatura socjalna, także w Czarnogórze przejęło rolę narzędzia propagandy ideologii wyzwolenia społecznego - z tym że z lokalnymi cechami, na przykład współczuciem wobec ofiar plagi głodu. Poeci Janko Đonović z jego programowym wierszem Crnci i Crnogorci czy Risto Ratković ilustrujący ,pochód głodnych wołających o chleb i sprawiedliwość" oraz sylwetki „robotnic śniących o kozach i krowach każdemu dających mleka / i czystych wymytych zębach” poddanych przemocy „Pana Monokla / przeliczającego za stołem zyski z kapitału"11 wykreowali obrazy zapoczątkowujące proces polityzacji wypowiedzi artystycznych, którego teoretycznym zapleczem stały się teksty Milana Bandovicia (Književnost kao socijalna funkcija - 1938) i Radovana Zogovicia (Formalizam i ob-

\footnotetext{
${ }^{10}$ Zob. np. Proglas CK KPJ crnogorskome narodu, „Naša borba” 1932, nr 18, ss. 90-91.

${ }^{11}$ Przykłady z wierszy Potucalo (1935), Pečalbarke (1936) i Beatriča (1937).
} 
jektivizam pod maskom naprednosti - 1940). Zogović jako fanatyczny wręcz postępowy realista, polemista w dyskusji o sztuce zaangażowanej z Miroslavem Krleža, a przy tym poeta o nieprzeciętnej wyobraźni i ideologiczny arbiter literacki po II wojnie światowej to wyjątkowe exemplum - tego jak niepospolite umysły twórcze oddawały się w służbę skrajnie dogmatycznego i zsowietyzowanego czarnogórskiego socjalizmu, natchnionego „kapłaństwem rewolucji”. Połowę łącznego nakładu książek wydanych w tym małym środowisku w latach międzywojennych stanowiła poezja.

Od początku procesu budowania partyzancko-titowskiej Jugosławii na fundamencie kadr armii (skutecznie zintegrowanej z rozdrobnionych oddziałów) do tej części kraju przylgnęła znana już z przeszłości etykieta ojczyzny chlubnej tradycji wolnościowej całego słowiańskiego Południa; w obecnej tu retoryce jej nieodłączny retoryczny wyznacznik stanowił zatem epitet slobodarski. Etos KPJ wzmacniany był na omawianym terenie nie tylko faktem przetrwania tej partii jako spójnej organizacji przez całą włoską - a od 1944 roku niemiecką - okupację, ale i uformowania ascetyczno-restrykcyjnego kodeksu zwyczajowego partyzantki, obejmującego zarówno kwestie cudzej własności, jak i stosunków damsko-męskich. Formalne i realne równouprawnienie czarnogórskich bojowniczek miało charakter pionierski na całych ziemiach jugosłowiańskich (przyjął się bliski tutejszej mentalności termin žena borac, równolegle do akcentującego ,hajducko-bałkański” indywidualizm partizan (ka) - początkowo używano też nieoficjalnie pojęcia gerilac, później urzędowego vojnik narodne vojske). W ślad za emancypacją wojskową poszła antypatriarchalna i społeczno-ekonomiczna edukacja w ramach specjalnych kursów dla kobiet. Od jesieni 1941 roku przywódcy ruchu narodowowyzwoleńczego występowali sporadycznie z hasłami ustanowienia „demokratycznej władzy ludowej”, chociaż po nieudanym powstaniu antywłoskim i przejściowych sukcesach ruchu czetnickiego formułowano je ostrożnie, nie chcąc pozbawić się zaplecza sił innych niż lewicowe; długo powstrzymywano się też przed tworzeniem „brygad proletariackich" Dopiero sukcesy Armii Czerwonej od 1942 roku pozwolą śmielej operować słowem-kluczem „socjalizm”, co odzwierciedlają decyzje prawne AVNOJ z listopada 1943 roku oraz pełne zastosowanie marksistowsko-leninowskiego słownika w czasopismach „Riječ slobode”, „Pobjeda” czy „Narodna borba”. Rozpoczęto też proces pozyskiwania „postępowych” duchownych prawosławnych. Symbolem pogardy dla wroga stał się zaś śmiejący się przed śmiercią w twarz egzekutorom partyzancki komisarz Ljubo Čupić.

${ }^{12}$ Szczegóły np. w: B. Jovanović, Crna Gora u NOR i socijalističkoj revoluciji, t. 1, Beograd, Vojno delo, 1960; Z. Lakić, Narodna vlast u Crnoj Gori 1941-1945, Cetinje-Beograd, Obod - Narodna knjiga, 1981. 
Jak wszędzie we wschodniej Europie, idee socjalistyczne zostały zaszczepione ze wzmocnieniem ,prawem bagnetu” i za sprawą autokratycznych organizacji - ze szkodą dla ich humanistycznego (Engelsowskie „od utopii do nauki”), a nie militarystycznego przesłania. $\mathrm{Z}$ tego również powodu związany z wojenną genezą syndrom „wojskowego szynela” objął początkowo stalinowską kategoryzację wrogów ludu czy spektakularne uwtaszczenie wywtaszczonych - dokonane pospiesznie i nieskutecznie w ramach nierealnej w warunkach górskich kolektywizacji lat 1947-1952 (część konfiskat majątków była sankcją wobec „zdrajców narodu”) ${ }^{13}$. Odgrywający przez ponad dwadzieścia lat rolę gospodarza kraju, nawykły do dyscypliny i hierarchii rusofil Blažo Jovanović twardą doktrynę komunistyczną skopiowaną z radzieckich dyrektyw partyjnych zabarwił jednak od początku elementami honorowej etyki wyrosłej z ludowej tradycji pieśni epickiej, akcentując w swych licznych i wielogodzinnych wystąpieniach wolnościowy egalitaryzm czy junacką dumę, a wartości marksizmu utożsamiając - w przełożeniu na postplemienny system wartości z prawdą, sprawiedliwością i uczciwością. Narodowy poemat Njegoša Gorski vijenac znał - jak wielu jego rodaków - na pamięć, a romantycznego poetę nazwał w wykładzie okolicznościowym w 1947 roku ,patronem i współtowarzyszem walki na sztandarach titowskiej ludowej armii" - sam przelanej krwi czetników nie uważając za braterską ${ }^{14}$. Nie był w tym myśleniu odosobniony, ponieważ podobnie kwalifikowali narodowego wieszcza inni apologeci nowego ustroju: Radovan Zogović podkreślał w jego epokowym dziele jako ,hymnie do walki rewolucyjnej” opór przeciwko kapitalistycznej Europie oraz wzór dla antyfeudalnego rozliczenia się z wrogami ludu (wytępienie poturczeńców), redaktorzy dziennika „Pobjeda” przypisywali z kolei poecie - wychowawcy „postępowych mas walczących” - rozróżnienie wojny spra-wiedliwej i niesprawiedliwej, pojęcie romantyzmu zastępowali „pierwotnym socrealizmem”, a ontologiczno-etyczną sentencję „Neka bude što biti ne može” odnosili personalnie do kierownictwa walki partyzanckiej ${ }^{15}$. Sam Jovanović swój charyzmat apostoła socjalizmu doskonalił jeszcze w czasie okupacji, rozsyłając umoralniające, utrzymane w konwencji heroiczno-marksistowskiej „posłania do plemion” podobne do sporządzanych półtora wieku wcześniej przez władykę Petara I, zaś gdy roztoczył swe panowanie nad jedną z ludowych republik federacji, zaktualizował

${ }^{13}$ Zob. D. Papović, Protivnici vlasti u Crnoj Gori 1945-1948, Cetinje-Podgorica, Matica crnogorska, 2009.

${ }^{14}$ B. Jovanović, [artykuł wstępny], „Pobjeda” 11.06.1947, s. 1. Zob. także D. Papović, Njegoš u socijalističkoj i nacionalnoj ideologiji Crne Gore 1945-1989, „Matica” 2013, nr 55, ss. 231-254 oraz prace Adnana Prekicia i Bobana Batrićevicia.

${ }^{15}$ R. Zogović, Njegoševa poema o borbi i slobodi, „Pobjeda” 11.06.1947, ss. 2,4 (później rozwinięte do formy książkowej); V. Džaković, O realizmu ,, Gorskog vijenca”, „Pobjeda” 5.03.1947, ss. 6-7; V. Pavićević, Njegoševo rodoljublje u „, Gorskom vijencu”, „Pobjeda” 19.01.1947, s. 6. 
postawę króla Nikoli sprzed 1918 roku - hojnie odpowiadając na tysiące indywidualnych próśb obywateli o finansową pomoc. Wizja monolitycznego społeczeństwa o bezkompromisowej jednomyślności i synowskiej miłości do władzy nie opuszczały go nawet wtedy, gdy w latach sześćdziesiątych stopniowo rozczarowywał się do własnego dzieła polityczno-państwowego, dostrzegając w nim narastającą korupcję i protekcjonalizm.

Kalendarz wydarzeń ogólnojugosłowiańskich, począwszy od konfliktu z Biurem Informacyjnym Międzynarodówki Komunistycznej w 1948 roku, miał w Czarnogórze swą charakterystyczną realizację wynikającą z paradoksalnego faktu, że to właśnie ta ostoja dogmatycznego zmilitaryzowanego marksizmu była jednocześnie ojczyzną Milovana Đilasa - jedynego Czarnogórca w ścisłym czteroosobowym kierownictwie partii i państwa do roku 1954, symbolu fermentu antybiurokratycznego (w nomenklaturze partyjnej - rewizjonistycznego) zmieniającego status Jugosławii w powojennym świecie europejskiego socjalizmu, filologa i autora ogromnego zbioru tekstów z pogranicza politologii, socjologii i filozofii, wielu z nich stworzonych z zacięciem literackim. Ta do dziś ze wszech miar niewygodna dla wielu stron sporu teoretycznego o wartości socjalistyczne i wpływająca raczej na środowisko belgradzkie postać odegrała kluczową rolę w przekierowaniu oficjalnej myśli titowskiej centrali na tory idei samorządowej - z jej czterema filarami: partią skupiająca wielonarodowe masy (a nie wyalienowane kadry aparatu), tzw. suwerenną (jugosłowiańską) drogą rewolucyjną do socjalizmu, rozbudowanym systemem samoorganizacji klasy pracującej oraz skonstruowaniem alternatywnego wobec moskiewskiej kurateli ruchu państw niezaangażowanych. Wcześniej, wysłany w latach 1941-1942 przez Titę z dwiema nieudanymi misjami do dźwigającej się do walki Czarnogóry jako mający powstrzymać skłonności swych rodaków do wendety w imię naruszonej czci, Đilas wyróżnił się przedwczesną nadgorliwością, ogłaszając fazę antyimperialistycznej rewolucji jeszcze przed powstaniem przeciw włoskim okupantom i tolerując w konwencji ekspedycji karnych setki morderstw na potencjalnych zwolennikach czetników (także w obrębie rodzin - na zasadzie zbiorowej odpowiedzialności znanej z czasów tureckich) oraz ich pochówek w zbiorowych grobach. Ta nieprzejednana pasja niszczenia przysporzyła mu w oczach partii oskarżeń o nieleninowskie „odchylenie ekstremistyczne” i rozpętywanie klasowej wojny domowej pod hasłami socjalistycznymi. Początkowo oddany bez reszty sprawie jednorazowego wyrównania rachunków społecznych (co zawarł później w myśli, iż istotą każdej rewolucji jest przesada) ${ }^{16}$, zaniechał wkrótce ambicji stworzenia przemocą pierwszej na Bałkanach republiki rad. Przemiana kata w antydogmatyka zaczęła się dokonywać już trzy lata po wojnie, kiedy na V Zjeździe KPJ (1948) obok własnego referatu na

${ }^{16}$ Zob. B. Kovačević, Đilas heroj-antiheroj, Podgorica, Pobjeda, 2006, s. 243. 
temat pracy agitacyjnej (ze standardową jeszcze retoryką antyfrakcyjną czy opisem walki z mistycyzmem, idealizmem i solipsyzmem w filozofii) ujawni swe oblicze jako przyszły ukryty współtwórca słynnego ,antymoskiewskiego” referatu Tity na VI Zjeździe (1952), gdzie rozproszone zostały już uwagi jego autorstwa o rewolucji autentycznej, współrządzeniu jednostek, wielonarodowym interesie państwowym, przewadze praktyki nad teorią czy niesprawiedliwych oskarżeniach ze strony wielkomarksistów ${ }^{17}$. Stając się z apologety Stalina sprawcą jego satanizacji, doświadczy wieloletnich wyroków z powodów innych niż ten pierwotny, by po latach oficjalnie ogłosić się dysydentem i po 1956 roku socjaldemokratą. W międzyczasie dozna bolesnego rozczarowania sytuacją w ojczystej Czarnogórze, trzymającej się po 1948 roku kurczowo linii dogmatycznej za przyczyną niedoinformowania i bezrefleksyjnego rusofilstwa, przekładanego tu na ślepy kult Stalina i w efekcie będzie świadkiem masowych (około 5 tysięcy osób) aresztowań na podstawie poszlak tych swoich współobywateli, którzy jego nowych antystalinowskich poglądów nie podzielali. Instrukcje w sprawie zmodyfikowanej linii partii przyjmowano w Titogradzie (pod taką nazwą aż do roku 1992) z niedowierzaniem i w rezultacie jej oponentów umieszczano bez zwłoki w reedukacyjnym obozie na Nagiej Wyspie. O partyjną litość nad krajem musiał upominać się jego pierwszy komunista Blažo Jovanović, stwierdziwszy zresztą niedługo później przewrotnie, iż przed radziecką biurokracją obronił republikę Njegoš wraz z KPJ ${ }^{18}$.

Jako jednoosobowe ,intelektualne skrzydło" partii i jedyny w jej kierownictwie poza Borisem Ziherlem - umysł filozoficzny kładący nacisk na kwestie pojęciowe, Đilas w odpowiedzi na moskiewskie naciski na przymusową integrację będzie kwestionować kolejne składniki stalinowskiej wykładni marksizmu. W łonie elity KPJ, gdzie zdarzali się co najwyżej znawcy ekonomii politycznej i wąskiej teorii walki klas (często sami próbujący tłumaczyć z rosyjskiego jej klasykę), nie miał konkurencji. Odpowiedź na zarzuty ze strony Międzynarodówki redagował z cichym wsparciem części aparatu w kilku fazach, z kulminacją w roku 1952, wychodząc od tezy przekształcania się radzieckiego socjalizmu w państwowy kapitalizm. Rozprawę ze swym niedawnym głównym autorytetem zaczął od krytyki klasycznej stalinowskiej redakcji Historii WKP $(b)(1938$, a w 1949 uznanej przez Zgromadzenie Ogólne Akademii Nauk ZSRR za wzorcowe dzieło encyklopedyczne), podając kolejno w wątpliwość następujące kategorie: ontologię postępu, dyktaturę proletariatu, leninowską koncepcję hierarchicznej i nadrzędnej partii, „algebrę rewolucji” w czasach pokoju

${ }_{17}$ J. Broz [Tito], Borba komunista Jugoslavije za socijalističku demokratiju, [w:] Šesti kongres KPJ [1952]. Stenografske bilješke, [b.m.w., b.r.w.], ss. 26-96. Zob. D. Leković, Milovan Đilas i socijalizam, Podgorica, CANU, 2010, ss. 270-272.

${ }^{18}$ Zob. B. Jovanović, Njegoš i njegovo vrijeme, „Pobjeda” 6.09.1951, s. 3. 
oraz ostateczną celowość bezklasowego społeczeństwa (zastępując je płynną socjalistyczną ideq w ruchu - co odczytano jako „piętno Bernsteina”), biurokratyczną strukturę władzy (to dawało mu z kolei znamię trockisty), sztuczne wywołanie rewolucji (echo teorii Karla Kautsky’ego) i jej identyczny dla wszystkich narodów przebieg, upartyjnienie gospodarki, dialektykę przemiany społecznej (pod tym kątem przeanalizował traktat Lenina Государство и революиия z 1917 roku) ${ }^{19}$.

Materiały do odparcia stalinowskich zarzutów zdobywał drogą kwerendy sam bądź z pomocą innego Czarnogórca, Dragutina Lekovicia - późniejszego studenta Raymonda Arona, lecz ich większość poznał z drugiej ręki. Dotyczyło to zwłaszcza kilkudziesięcioletniej historii polemik marksistów rosyjskich z niemieckimi, którą wykorzystał do uargumentowania hegemonizmu, etatyzmu i monolityzmu w ZSRR. Obok wspomnianego Bernsteina (opozycja „materia - idea”) wpływały na niego poglądy Trockiego na scentralizowany „wyalienowany socjalizm” (znał stenogramy procesów trockistów, także bezpośrednio z Moskwy), rosyjscy syndykaliści, Nikołaj Bucharin, Bakunin z jego krytyką „arystokracji funkcjonariuszy”, myśli Róży Luksemburg o socjalizmie demokratycznym, nawet brytyjscy labourzyści, z którymi utrzymywał kontakty. Przede wszystkim wszak radzieckiemu modelowi „materialistyczno-biurokratycznemu" przeciwstawił wyrastający bez wątpienia z korzeni czarnogórskiego heroizmu ,socjalizm etyczny”, łączący odwagę z humanitaryzmem bojownika broniącego każdej pokrzywdzonej ludzkiej wspólnoty ${ }^{20}$. Wobec pogłębiających się rozdźwięków odchodził w swych tekstach od 1952 roku od łagodnej terminologii typu „samostanowienie”, ,suwerenność”, „,równoprawność”, kierując do radzieckich towarzyszy oskarżenia o „despotię i system kastowy”, ,zamęt ideowy i duchowy zastój”, „zdradę ideałów Października”, zarazem Titę uznając za „rewolucyjną i plebejską osobowość”, a „ciagły ruch i walkę” za sedno wolności ${ }^{21}$. W 1957 roku w Nowej klasie rewolucje komunistyczne określi już mianem „największych oszustw historycznych", rekonfigurujących tylko zastany układ klas społecznych ${ }^{22}$.

Odsłaniając w nieprawomyślny sposób kolejne aspekty praktyki ustrojowej socjalizmu, Đilas pogrążał się do 1954 roku coraz bardziej, popadając ostatecznie w niełaskę w samej Czarnogórze, gdzie odważył się między innymi prezentować swe poglądy w kwestiach wolności ekonomicznej, tzw. zamaskowanego pasożytnictwa

${ }^{19}$ Zob. D. Leković, Milovan Đilas..., op. cit., s. 282-305 oraz M. Zacharias, Idee, utopie, rzeczywistość. Myśl polityczna Milovana Đilasa (1911-1995), Bydgoszcz, Wydawnictwo UKW, 2015. Prócz tej przykładowej książkowej pozycji bibliograficznej polskie piśmiennictwo naukowe zawiera bardzo dużą - tu pomijaną - liczbę studiów na temat tytułowej postaci, ogromne jest też zaplecze analogicznych tekstów anglo- i serbskojęzycznych.

${ }^{20}$ Zob. D. Leković, Milovan Đilas..., op.cit., ss. 91-129, 436-437.

${ }^{21}$ Zob. Šesti kongres..., op.cit., s. 398; M. Đilas, Ima li cilja, „Borba” 6.12.1953, s. 3; D. Leković, Milovan Đilas..., op.cit., s. 275.

${ }^{22}$ M. Đilas, Nova klasa, Beograd, Narodna knjiga, 1990, s. 36. 
i detechnokratyzacji czy konieczności istnienia dwóch partii socjalistycznych (ZKJ sam zresztą i tak w końcu uległ wewnętrznej decentralizacji). Po nadzwyczajnym plenum KC ZKJ nastąpiło samowykluczenie z partii i wkrótce kilkuletni wyrok z paragrafu „wrogiej propagandy” wraz z pozbawieniem stopnia generała. Nim otworzy to $\mathrm{w}$ jego życiu okres nowych publikacji jako już byłego komunisty, symbolicznie zamknie czas trwania fundacyjnej fazy jugosłowiańskiego socjalizmu samorządowego. Jego geneza okazała się splotem wielu przypadkowych często korzystnych okoliczności. Przełomową ustawę o radach pracowniczych w myśl dosłownie rozumianego hasła „Fabryki - robotnikom!” uchwalono z oporami w 1950 roku nie bez zachęt Đilasa i z dalekim wsparciem teorii wolnej wytwórczości Proudhona i Johanna Gottlieba Fichtego, a także Svetozara Markovicia, po czym wprowadzono zasadę swobodnego podziału dochodu - co Tito potem niejednokrotnie określał jako „twórcze rozwinięcie podstaw socjalizmu” ku jego „efektywnej humanizacji”"23. Jest to właśnie jeden z przykładów odciśnięcia ,śladu Đilasa” - postrzegającego socjalizm w wymiarze antropologicznym, w aspekcie nieśmiertelnego ideału wolności, ofiary bohaterskiej i głębokiego sensu sprawiedliwości, co ilustrują już jego artykuły z okresu 1953-54 akcentujące „ideę wolnego myślenia” czy „młodość i piękno” idei równości ${ }^{24}$. Po latach, w Społeczeństwie niedoskonatym (1969) wyzna, że - w ostateczności uznany za utopijny - projekt samorządowy dojrzał jeszcze w 1949 roku po weryfikującej lekturze III tomu Marksowskiego Kapitatu (bez uwzględnienia jego krytyki rozwiązań Komuny Paryskiej) ${ }^{25}$, przy czym początkowo rola opiekuńczego państwa sprowadzać się w nim miała wyłącznie do ściągania podatków $\mathrm{z}$ grona niezależnych wytwórców.

U najbardziej po Ticie znanego jugosłowiańskiego oponenta Stalina ewolucja ku legalizmowi i reformizmowi wynikała nie $\mathrm{z}$ awersji do samej istoty rewolucji, lecz do jej strony destrukcyjnej i dehumanizującej zbiorową świadomość. Światopogląd swój wyostrzył po wydarzeniach węgierskich w anglojęzycznej Nowej klasie (1957), występując przeciw negacji wolności przez komunistyczną biurokrację zawłaszczającą wartość dodatkową wypracowaną przez pozbawionych prawa do strajku robotników, a ta diagnoza z czasem ułatwiła szersze przyjęcie się w międzynarodowej terminologii pojęcia nomenklatury. Jeszcze dalej poszedł we wspomnianym dziele Spoleczeństwo niedoskonałe, gdzie pisząc w więziennych warunkach o swej odległej przeszłości „dogmatyka przemocy”, przekreślił ją akceptując tylko model humanizmu egzystencjalnego Mahatmy Gandhiego, pokornej walki o społeczną równość. Socjalizm staje się w takim ujęciu prometejskim „fanatyzmem wolności”

${ }^{23}$ Zob. Tito, SKJ, samoupravni socijalizam, red. P. Gregorić et al., Zagreb, Spektar, 1975, ss. 148, 201.

${ }^{24}$ M. Đilas, Savez ili partija, „Borba” 4.01.1954, s. 4.

${ }^{25}$ Zob. M. Đilas, Nesavršeno društvo, Beograd, Narodna knjiga, 1990, s. 139. 
człowieka-artysty naznaczonego „bałkańską buntowniczością przeoraną filozofiami racjonalistycznymi" ${ }^{26}$. Dialektykę heglowską uzasadniającą przemoc uzna Đilas za „sztucznie zmaterializowaną" i nienaukową na obszarach innych niż historia i socjologia, prowadząc $\mathrm{w}$ tej kolejnej eklektycznej rozprawie z pozorami naukowości marksizmu w wersji radzieckiej wiele wątków ontologicznych, etycznych, a nawet fizycznych i biologicznych. Wykorzystuje też do tego argumenty egzystencjalistów, młodego Leszka Kołakowskiego, Benedetto Croce, w tle pojawi się również Nikołaj Bierdiajew. W przedziwnej syntezie autorytetów poczesne miejsce przypada adaptacji czarnogórskiej sentencji „Nie wie nigdy człowiek, w jakiej wierze umrze”, pozwalającej mu między innymi na polemikę z Simone de Beauvoir w sprawie idealizacji przez nią małych ascetycznych wspólnot ceniących niematerialne wartości (przy założeniu Đilasa, że spełniający owo kryterium Czarnogórcy bynajmniej nie stali się przez to automatycznie lepszymi ludźmi). Cała logika wywodu rewidującego wulgaryzację nieosiągalnych kolektywnych ideałów antycypuje tu jednocześnie nadchodzące globalne przemiany społeczne: autor dostrzega mianowicie szanse mieszanej gospodarki państwowo-prywatnej na przykładzie przyszłej wyobrażonej wspólnoty czarnogórskich chłopów i walijskich górników, konsekwencje łopotu „czerwonych sztandarów 1968 roku", uwiąd gospodarki Zachodu bez rynku rosyjskiego, automatyzację pracy i wreszcie dekompozycję federacyjnej Jugosławii ${ }^{27}$.

Newralgiczny do dziś problem „mentalnej czarnogórskości” Đilasa wyjaśnia częściowo jedno z jego późnych osobistych wyznań:

„Njegoš wzmacniał mój umysł poezją czerpiącą ze [...] stuletnich kosmicznych cierpień, a wojewoda Marko [Miljanov] zobowiązywał swą poetycką etycznością [...] bym nie zdradził jego i swojej Czarnogóry”28.

Njegošowski wątek walki kosmicznej i ofiary ziemskiego cierpienia składanej przez ascetę strzegącego się pokus codzienności powróci w jednej z ostatnich, mniej już znanych książek Tamnica i ideja (1984), której symboliczny tytuł przeciwstawia upokorzenie bytowania w więziennej ciemnicy światłu absolutnego wyzwolenia. Całkowitemu wyrzeczeniu się zideologizowanej przemocy towarzyszy w niej apoteoza uniwersalnych idei niepolitycznych jako jedynych wyposażonych w moc twórczego wcielania się w ludzi i organizacje. Takie właśnie koncepcje, łączące się zawsze z naczelną kategorią życia, mają szanse samoograniczać się, gdy zagrozi im egoizm rozumu partykularnego lub wykorzystanie w celu rozbicia naturalnych ludzkich wspólnot. Stąd też idei socjalizmu (,nie mającej litości nad tymi, którzy ją

\footnotetext{
${ }^{26}$ Ibidem, s. 161.

${ }^{27}$ Ibidem, ss. 117, 125, 130, 136, 147.

${ }^{28}$ M. Đilas, Crna Gora kao zavičaj [1976], „NIN” 24.08.2006, s. 44.
} 
zrodzili”) obiektywizm nadaje jedynie jej utożsamienie z wolnością, dzięki któremu może w tym przypadku istnieć ,absolutna wiara w nieabsolutną ideę"29. Ponownie zatem zwycięża jej etyczny, a nie ekonomiczno-unifikacyjny wymiar, gdyż - jak czytamy - „wieloutopijność” ludzkiego bytu spełnić się może wyłącznie w socjalizmie pluralistycznym - co w przełożeniu na język społecznej praktyki oznacza prymat sprawiedliwego prawa i zastapienie „niewolniczo-feudalnej” własności społecznej grupową. Dylematy Đilasa okazują się więc w końcu projekcją moralnego oburzenia, któremu trudno było odnaleźć się w świecie przyziemnych spraw oswajania materii, przekleństwa własności czy też eliminacji wroga ideowego.

Na etyczny maksymalizm Czarnogórców nawykłych do częstego obcowania z sytuacjami granicznymi wielokrotnie w nowych warunkach się powoływano, co uczynił choćby prozaik Mihailo Lalić w monumentalnej powieści partyzanckiej Lelejska gora (1957), przypominając że obsesją tutejszego człowieka jest organiczna więź z hermetyczną grupą społeczna, pozwalająca powstrzymać okrucieństwo świata natury i podstępy nieprzyjaciół. Wcześniej twórca wydał pionierski tom opowiadań socrealistycznych Izvidnica (1949), inni - jak Mirko Banjević - przeszli do historii literatury jako pełni uniesienia piewcy śmierci. Kolejny rys specyficzny lokalnej sytuacji w pierwszych powojennych dekadach polegał na tym, że podczas gdy zachodni politolodzy do lat siedemdziesiątych grzmieli o bolszewickim protestantyzmie, dyktaturze partycypacyjnej czy autorytarnej modernizacji w SFRJ, Czarnogóra doświadczała bezprzykładnego awansu gospodarczo-konsumpcyjnego, edukacyjnego i po części kulturalnego. Bardzo wysoki był stopień ateizacji. System jednopartyjny stawiający na sprawiedliwy materialny dobrobyt wpisywał się zarówno w tradycje wzorców ustrojowych monarchii absolutnej (sprzed 1918 roku), jak i egalitarnego plemiennego prawa zwyczajowego - czemu sprzyjał nawet nad wyraz skromny sposób bycia kolejnych głównych decydentów Komunistycznej Partii Czarnogóry, Veselina Đuranovicia czy Veljko Milatovicia. Warta przypomnienia jest również sylwetka Veljko Vlahovicia, który w latach 1941-1944 odegrał znacząca rolę w procesie uświadamiania mas wielu narodów, kierując moskiewską rozgłośnią „Slobodna Jugoslavija” (nadającą w systemie Kominternu) - później odpowiadał w KC ZKJ za pracę agitacyjno-ideologiczną w całej Jugosławii, a jego popiersie uroczyście odsłonięto w Podgoricy w roku 2016, zastępując już w okolicznościowych laudacjach zdyskredytowany termin „,ruch komunistyczny” ruchem „międzynarodowym”, co miało przeciwstawić semantykę internacjonalistycznej solidarności wszystkim późniejszym etnonacjonalizmom wybuchającym w regionie. Za głosem kolejnego naczelnego belgradzkiego ideologa samorządowości, Edvarda Kardelja,

${ }^{29}$ M. Đilas, Tamnica i ideja, Beograd, Trag, 1989, ss. 21, 22. Zob. także: D. Leković, Savremene revolucije - svojina i sloboda, „Luča” 1995, nr 1-2, ss. 110-130. 
aktywiści czarnogórscy przez ostatnią dekadę życia Tity powielali jeszcze znaczeniowe matryce o urzeczywistnieniu Marksowskiej republiki pracy, praktycznej szkole humanistycznych stosunków produkcji czy realnej adaptacji tekstów marksizmu bez ich rytualnego cytowania. Przydatny na każdą okazję Njegoš z socjalisty utopijnego i komisarza politycznego staje się w tym czasie w oczach wielu Jugosłowianinem. W dysputach teoretycznych podczas tzw. rozmów nad Tarą (razgovori na Tari) w przededniu śmierci marszałka zaczęto już z pozycji krytycznych dostrzegać finansowe wyobcowanie banków, handlu oraz towarzystw ubezpieczeniowych, separatyzm gospodarczy republik federacji oraz ,rozdrobnienie klas”, jednak lokalne partyjne zjazdy nadal występowały przeciw „socjalizmowi z epitetami” czy „,nauce mieszczańskiej”"30, a wspierało je merytorycznie od 1977 roku naukowe ramię uniwersyteckiego Wydziału Marksizmu i Samorządności Socjalistycznej w Nikšiciu. Przywódca państwa wciąż tymczasem twierdził, że nie ma w nim konfliktu pokoleń, ponieważ młodzież została przepojona „rewolucyjnym duchem” ${ }^{31}$. Wkrótce okaże się wszak, że próby połowicznej reformy ustroju, podobnie jak w końcu lat czterdziestych, natrafią na opór konserwatywnych neostalinistów - część z nich w latach osiemdziesiątych nadal postulowała wręcz inspirowanie antykapitalistycznych powstań zbrojnych w krajach zachodnich.

Dramatyczny finał zinstrumentalizowanej obrony praw „człowieka pracy” nastąpił w wyniku tzw. rewolucji antybiurokratycznej (1987-1989), gdy - pod maską solidarności z kosowskimi Serbami i z wykorzystaniem w odgórnie sterowanych mityngach skostniałej frazeologii społeczno-ekonomicznej - zdołano wymienić z niechlubnym wsparciem świata uniwersyteckiego całe kierownictwo republiki na lojalne wobec nowej nacjonalistycznej linii reprezentowanej w Belgradzie przez Slobodana Miloševicia. Był to jeden z kluczowych od czasów okupacji momentów przecięcia się restaurowanych interesów serbskich z czarnogórskimi, orientacji socjalistycznej z odradzającą się narodową oraz przedświt wydarzeń z lat dziewięćdziesiątych i późniejszych. Rozpoczęła się dezintegracja dotychczasowego systemu politycznego i dekoncentracja spoiwa ideowego, prowadząca przez meandry konfliktów zbrojnych, samouwłaszczenia partyjnej biurokracji we wszystkich byłych republikach związkowych, utratę systemowej kontroli nad produkcją, zwrot nacjonalistyczny w kulturze i opisie dziejów oraz rozwój tendencji autonomistycznych na poziomie państwa. Na placu boju, jako organizacja wierna ortodoksyjnym fundamentom, pozostała od 2009 roku Jugosłowiańska Komunistyczna Partia Czarnogóry, programowo opowiadająca się obecnie za pokojową renacjonalizacją środków pro-

${ }^{30}$ Zob. np. XI Zjazd Zwiazku Komunistów Jugosławii. Podstawowe dokumenty, Warszawa, Książka i Wiedza, 1979, s. 84.

${ }^{31}$ Tę retorykę przywódca stosował już w końcu lat pięćdziesiątych (np. w przemówieniu do drogowych brygad pracy [1958]) - zob. Tito, SKJ..., op.cit., s. 219. 
dukcji (przy zachowaniu ostrych metod rewolucyjnych tylko na skoordynowanym poziomie międzynarodowym) i cementowaniem świadomości nowego proletariatu w krajach o „półkolonialnym typie gospodarki”, gdzie dokonano „rozboju prywatyzacji" ${ }^{32}$. Ze względu na głębokie - i jak nigdzie indziej powszechne - doświadczenie pokoleniowe Czarnogórców, służących wiernie jugosłowiańskiemu państwu w administracji, siłach zbrojnych, i na licznych byłych prominentnych funkcjonariuszy nadbudowy ideologicznej, w kraju w zasadzie nie zdecydowano się na dokonanie procesu mającego w innych państwach postsocjalistycznych - na przykład w Serbii naturę dekomunizacji sfery symbolicznej. Jej dawna tożsamość wywołuje też wiele pozytywnych asocjacji starszych słowiańskich muzułmanów czy Albańczyków. W ostatnich latach pogłębiało się poza tym rozwarstwienie życia politycznego na lewicowe z zasady partie proczarnogórskie i prawicowe proserbskie, a gdy proklamowano (1993) odnowienie wciąż oczekującej na uznanie międzynarodowe Czarnogórskiej Cerkwi Prawosławnej, kręgi Cerkwi Serbskiej natychmiast skierowały przeciw niej zarzut, iż została powołana do życia z inspiracji „przechrzczonych” komunistów.

Ten i inne paradoksy nie zamykają trudnej drogi zacieśniania, a następnie zrywania więzi niewielkiego, tradycjonalistycznego i początkowo ekonomicznie zacofanego społeczeństwa $\mathrm{z}$ ideologią oferującą mu przyspieszoną emancypację i gwarancję zachowania sprawiedliwości. Inspiracje niemieckie, serbskie oraz rosyjsko-radzieckie odegrały pierwotnie w jej recepcji rolę katalizatora przemiany świadomości postpatriarchalnej (w wariancie plemienno-militarnym) w proletariacka, której uproszczone rozumienie przyniosła dogmatyczna stalinowska adaptacja teorii rewolucyjnego marksizmu. Nigdy nie pierwszoplanowy w Czarnogórze konflikt klasowy został po jej odrzuceniu w 1948 roku zastapiony jako ideowy punkt odniesienia lokalną odmianą etosu samorządowego obudowanego kultem epopei partyzanckiej, a uwarunkowania miejscowej tradycji zsyntezowały wszystkie te elementy w niepowtarzalnym połączeniu ideałów heroizmu, wierności zasadom kanonu moralnego, pokoleniowej hierarchii i równości obowiązków. Takie też wartości uzupełniały od lat trzydziestych publicystyczne i artystyczne manifestacje lewicowych światopoglądów nielicznych pochodzących stąd autorów. Kiedy zaś znieruchomiały one wszystkie w oficjalnej doktrynie socjalizmu biurokratycznego, odważna refleksja Milovana Đilasa przywróciła im świeżość, rewidując od podstaw większość znaczeń kostniejącej teorii i wpisując się w tok wielkiego współzawodnictwa między światowymi blokami politycznymi, które rozdzielała stworzona ze skromnym czarnogórskim udziałem w wielonarodowym jugosłowiańskim państwie „,ideologiczna platforma” titoizmu.

${ }^{32}$ Politički program Jugoslovenske komunističke partije Crne Gore [2012], [w:] http://www. jkpcg.me/dokumenta/Program.pdf [dostęp: 20.03.2020]. 


\section{Literatura}

Broz [Tito] J., Borba komunista Jugoslavije za socijalističku demokratiju, [w:] Šesti kongres KPJ [1952]. Stenografske bilješke, [b.m.w., b.r.w.], ss. 26-96.

Bujwid-Kurek E., Myśl polityczna i państwowo-ustrojowa Svetozara Markovicia (1846-1875), Księgarnia Akademicka, Kraków 2000, 207 ss.

Crna Gora, red. M. Maletić, Beograd, Književne novine - Stručna knjiga, 1976, 997 ss.

Džaković V., O realizmu ,, Gorskog vijenca”, „Pobjeda” 5.03.1947, ss. 6-7.

Đilas M., Crna Gora kao zavičaj [1976], „NIN”24.08.2006, ss. 43-45.

Đilas M., Ima li cilja, „Borba” 6.12.1953, s. 3.

Đilas M., Nesavršeno društvo, Beograd, Narodna knjiga, 1990, 180 ss.

Đilas M., Nova klasa, Beograd, Narodna knjiga, 1990, 205 ss.

Đilas M., Savez ili partija, „Borba” 4.01.1954, s. 4.

Đilas M., Tamnica i ideja, Beograd, Trag, 1989, 192 ss.

Jovanović B., Crna Gora u NOR i socijalističkoj revoluciji, t. 1, Beograd, Vojno delo, 1960, 867 ss.

Jovanović B., Njegoš i njegovo vrijeme, „Pobjeda” 6.09.1951, ss. 2-3.

Kovačević B., Đilas heroj - antiheroj, Podgorica, Pobjeda, 2006, 548 ss.

Kusovac M., Odnos Crne Gore i Rusije, „Matica” 2013/2014, nr 56-57, ss. 53-72.

Lakić Z., Narodna vlast u Crnoj Gori 1941-1945, Cetinje-Beograd, Obod - Narodna knjiga, 1981, 547 ss.

Leković D., Milovan Đilas i socijalizam, Podgorica, CANU, 2010, 586 ss.

Leković D., Savremene revolucije - svojina i sloboda, „Luča” 1995, nr 1-2, ss. 110-130.

Marović B., Ekonomska istorija Crne Gore, Podgorica, CID, 2006 (t. I), 484 ss.; Pobjeda, 2008 (t. II), 520 ss.

Papović D., Njegoš u socijalističkoj i nacionalnoj ideologiji Crne Gore 1945-1989, „Matica” 2013, nr 55, ss. 231-254.

Papović D., Protivnici vlasti u Crnoj Gori 1945-1948, Cetinje-Podgorica, Matica crnogorska, 2009, 281 ss.

Pavićević V., Njegoševo rodoljublje u „Gorskom vijencu”, „Pobjeda” 19.01.1947, ss. 6-7.

Pejović Č., Komunistička partija Jugoslavije u Crnoj Gori 1919-1941, Podgorica, CID, 1999, 509 ss.

Pejović Đ., Društveno-filozofski pogledi u Crnoj Gori od početka XIX do sredine XX vijeka, Titograd, CANU, 1980, 245 ss.

Pisarek H., Filozofia Svetozara Markovicia (1846-1875): z historii marksizmu w Serbii, Wrocław, Wydawnictwo Uniwersytetu Wrocławskiego, 1981, 208 ss.

Politički program Jugoslovenske komunističke partije Crne Gore [2012], [w:] http:// www.jkpcg.me/dokumenta/Program.pdf [dostęp: 20.03.2020]. 
Povijest Saveza komunista Jugoslavije, red. S. Stojanović et al., Beograd, Komunist, 1985, 478 ss.

Požar P., Jugosloveni žrtve staljinskih čistki, Beograd, Nova knjiga, 1989, 368 ss.

Proglas CK KPJ crnogorskome narodu, „Naša borba” 1932, nr 18, ss. 90-91.

Radonjić R., Socijalizam u Crnoj Gori, Podgorica, Matica crnogorska, 2013, 704 ss.

Raspopović R., Crna Gora i Rusija: ogledi i eseji, Podgorica, Istorijski institut Crne Gore, 2005, 429 ss.

Tito, SKJ, samoupravni socijalizam, red. P. Gregorić et al., Zagreb, Spektar, 1975, 332 ss.

Vujović D., Učešće Vukašina Markovića u oktobarskoj revoluciji i njeni odjeci u Crnoj Gori, [w:] Prilozi za istoriju socijalizma, t. 5, red. P. Damjanović et al., Beograd, Institut za izučavanje radničkog pokreta, 1968, ss. 501-508.

Zacharias M., Idee, utopie, rzeczywistość. Myśl polityczna Milovana Đilasa (19111995), Bydgoszcz, Wydawnictwo UKW, 2015, 277 ss.

Zogović R., Njegoševa poema o borbi i slobodi, „Pobjeda” 11.06.1947, ss. 2-5. Жанна Лябурб - франиуженка в Одессе, [w:] https://agesmystery.ru/rubriki/zagovory-i-afery/zhanna-lyaburb-francuzhenka-v-odesse/ [dostęp: 20.03.2020].

XI Zjazd Zwiqzku Komunistów Jugosławii. Podstawowe dokumenty, Warszawa, Książka i Wiedza, 1979, 296 ss.

\section{References}

Broz [Tito] J., Borba komunista Jugoslavije za socijalističku demokratiju [The Struggle of the Yugoslav Communists for Socialist Democracy], [in:] Šesti kongres KPJ [1952]. Stenografske bilješke [n.p., n.d.], pp. 26-96.

Bujwid-Kurek E., Myśl polityczna i państwowo-ustrojowa Svetozara Markovicia (1846-1875) [Political-System and State Thought of Svetozar Markovic (18461875)], Księgarnia Akademicka, Kraków 2000, 207 pp.

Džaković V., O realizmu "Gorskog vijenca" [About Realism in "Gorski vijenac"], "Pobjeda" 5.03.1947, pp. 6-7.

Đilas M., Crna Gora kao zavičaj [Montenegro as a Homeland] [1976], "NIN" 24.08.2006, pp. 43-45.

Đilas M., Ima li cilja [Does the Aim Exist?], "Borba", 6.12.1953, p. 3.

Đilas M., Nesavršeno društvo [The Unperfect Society], Beograd, Narodna knjiga, 1990, $180 \mathrm{pp}$.

Đilas M., Nova klasa [A New Class], Beograd, Narodna knjiga, 1990, 205 pp.

Đilas M., Savez ili partija [Union or Party], "Borba" 4.01.1954, p. 4.

Đilas M., Tamnica i ideja [A Dungeon and Idea], Beograd, Trag, 1989, 192 pp. 
Gregorić P. et al. (Eds.), Tito, SKJ, samoupravni socijalizam [Tito, UCY, Self-government Socialism], Zagreb, Spektar, 1975, 332 pp.

Jovanović B., Crna Gora u NOR $i$ socijalističkoj revoluciji [Montenegro in the People's Liberation War and Socialist Revolution], vol. 1, Beograd, Vojno delo, 1960, 867 pp.

Jovanović B., Njegoš i njegovo vrijeme [Njegoš and His Time], "Pobjeda" 6.09.1951, pp. 2-3.

Kovačević B., Đilas heroj-antiheroj [Đilas: Hero - Anti-hero], Podgorica, Pobjeda, 2006, 548 pp.

Kusovac M., Odnos Crne Gore i Rusije [The Relation Between Montenegro and Russia], "Matica" 2013/2014, no. 56-57, pp. 53-72.

Lakić Z., Narodna vlast u Crnoj Gori 1941-1945 [People's Authority in Montenegro 1941-1945], Cetinje-Beograd, Obod - Narodna knjiga, 1981, 547 pp.

Leković D., Milovan Đilas i socijalizam [Milovan Đilas and Socialism], Podgorica, CANU, 2010, $586 \mathrm{pp}$.

Leković D., Savremene revolucije - svojina i sloboda [Contemporary Revolutions - Ownership and Liberty], "Luča", 1995, no. 1-2, pp. 110-130.

Maletić M. (Ed.), Crna Gora [Montenegro], Beograd, Književne novine - Stručna knjiga, 1976, 997 pp.

Marović B., Ekonomska istorija Crne Gore [An Economic History of Montenegro], Podgorica, CID, 2006 (vol. I), 484 pp.; Pobjeda, 2008 (vol. II), 520 pp.

Papović D., Njegoš u socijalističkoj i nacionalnoj ideologiji Crne Gore 1945-1989 [Njegoš in Socialist and National Ideology of Montenegro 1945-1989], "Matica" 2013, no. 55, pp. 231-254.

Papović D., Protivnici vlasti u Crnoj Gori 1945-1948 [Opponents of Authority in Montenegro 1945-1948], Cetinje-Podgorica, Matica crnogorska, 2009, 281 pp.

Pavićević V., Njegoševo rodoljublje u "Gorskom vijencu" [The Njegoš' Patriotism in "Gorski vijenac"], "Pobjeda", 19.01.1947, pp. 6-7.

Pejović Č., Komunistička partija Jugoslavije u Crnoj Gori 1919-1941 [A Yugoslav Communist Party in Montenegro 1919-1941], Podgorica, CID, 1999, 509 pp.

Pejović Đ., Društveno-filozofski pogledi u Crnoj Gori od početka XIX do sredine XX vijeka [Socio-philosophical Views in Montenegro From the Beginning of $19^{\text {th }}$ to the End of 20 ${ }^{\text {th }}$ Century], Titograd, CANU, 1980, $245 \mathrm{pp}$.

Pisarek H., Filozofia Svetozara Markovicia (1846-1875): z historii marksizmu w Serbii [Svetozar Markovic's Philosophy (1846-1875): from the History of Marxism in Serbia], Wrocław, Wydawnictwo Uniwersytetu Wrocławskiego, 1981, 208 pp. Politički program Jugoslovenske komunističke partije Crne Gore [A Political Programme of the Yugoslav Communist Party of Montenegro] [2012]. Available at: http://www.jkpcg.me/dokumenta/Program.pdf [accessed: 20.03.2020]. 
Požar P., Jugosloveni žrtve staljinskih čistki [The Yugoslavs - Victims of Stalin's Persecuting], Beograd, Nova knjiga, 1989, 368 pp.

Proglas CK KPJ crnogorskome narodu [A Message of Central Commitee of YCP to the Montenegrin People], "Naša borba" 1932, no. 18, pp. 90-91.

Radonjić R., Socijalizam u Crnoj Gori [Socialism in Montenegro], Podgorica, Matica crnogorska, 2013, 704 pp.

Raspopović R., Crna Gora i Rusija: ogledi i eseji [Montenegro and Russia: Sketches and Essays], Podgorica, Istorijski institut Crne Gore, 2005, 429 pp.

Stojanović S. et al. (Eds.), Povijest Saveza komunista Jugoslavije [The History of Communists Union of Yugoslavia], Beograd, Komunist, 1985, 478 pp.

Vujović D., Učešće Vukašina Markovića u oktobarskoj revoluciji i njeni odjeci u Crnoj Gori [The Participation of Vukašin Marković in the October Revolution], [in:] Prilozi za istoriju socijalizma, P. Damjanović et al. (Eds.), vol. 5, Beograd, Institut za izučavanje radničkog pokreta, 1968, pp. 501-508.

Zacharias M., Idee, utopie, rzeczywistość. Myśl polityczna Milovana Đilasa (19111995) [Ideas, Utopias, Reality. Political Thought of Milovan Đilas (1911-1995)], Bydgoszcz, Wydawnictwo UKW, 2015, 277 pp.

Zhanna Liaburb - frantsuzhenka $v$ Odesse [Jeanne Labourbe - the Frenchwoman in Odessa]. Available at: https://agesmystery.ru/rubriki/zagovory-i-afery/zhannalyaburb-francuzhenka-v-odesse/ [accessed: 20.03.2020].

Zogović R., Njegoševa poema o borbi i slobodi [Njegoš's Poem About Struggle and Liberty], "Pobjeda", 11.06.1947, pp. 2-5.

XI Zjazd Zwiqzku Komunistów Jugosławii. Podstawowe dokumenty [The $11^{\text {th }}$ Congress of the UCY. The Fundamental Documents], Warszawa, Książka i Wiedza, 1979, $296 \mathrm{pp}$. 
